\title{
Upaya Meningkatkan Kinerja Guru Pendidikan Agama Islam (PAI) di Masa Pandemik Covid-19 dengan Pembinaan dan Pemantauan Menggunakan Google Form
}

\author{
Musbahaeri \\ Kementerian Agama Kabupaten Bulukumba, Bulukumba, 92511, Indonesia \\ *email: musbahaeri9699@gmail.com
}

\begin{abstract}
Abstrak
Pandemik Covid-19 berdampak pada pelaksanaan pembelajaran di sekolah. Demikian halnya pelaksanaan pembinaan dan pemantauan oleh pengawas. Pembinaan dan pemantauan oleh pengawas diharapkan mampu mengendalikan proses pembelajaran di masa pandemik. Pengawas diharapkan mampu menjaga stabilitas kinerja guru dalam melaksanakan pembelajaran di masa pandemik walaupun menghadapi berbagai keterbatasan dan kendala teknis. Tujuan penelitian ini adalah untuk meningkatkan kinerja guru PAI di masa pandemik Covid-19 dengan pembinaan dan pemantauan menggunakan Google Form. Metode yang digunakan adalah survey. Adapun responden penelitian ini adalah 27 guru sekolah menengah atas di Kabupaten Bulukumba. Temuan penelitian ini adalah Google Form dapat menunjang upaya peningkatan kinerja guru PAI di masa Covid-19. Dari hasil pemantauan dan pembinaan dengan menggunakan Google Form tergambar bahwa kinerja guru, khususnya guru PAI binaan, menunjukkan tingkat yang berbeda-beda dipengaruhi oleh pola pikir, tingkat kompetensi penggunaan Learning Management System (LMS), dan ketersediaan jaringan internet. Implikasi penelitian ini adalah perlunya diadakan workshop untuk meningkatkan kompetensi guru, terutama dalam pemanfaatan media pembelajaran online.
\end{abstract}

Kata Kunci: Pembinaan, pemantauan, kinerja guru

\begin{abstract}
Abstact
The Covid-19 pandemic has affected the implementation of learning in schools. Likewise the implementation of coaching and monitoring by supervisors. Guidance and monitoring by supervisors are expected to be able to control the learning process during the pandemic. Supervisors are expected to be able to maintain the stability of teacher performance in carrying out learning during the pandemic despite facing various technical limitations and obstacles. The purpose of this study is to improve the performance of PAI teachers during the Covid-19 pandemic by coaching and monitoring using Google Form. The method used is a survey. The respondents of this study were 27 high school teachers in Bulukumba Regency. The findings of this study are that Google Form can support efforts to improve the performance of PAI teachers during the Covid-19 period. From the results of monitoring and coaching using Google Form, it
\end{abstract}


can be seen that the performance of teachers, especially the assisted PAI teachers, shows that different levels are influenced by mindsets, competency levels in using the Learning Management System (LMS), and the availability of internet networks. The implication of this research is the need to hold workshops to improve teacher competence, especially in the use of online learning media.

Keywords: Coaching, monitoring, teacher performance

\section{Pendahuluan}

Di akhir Desember 2019 dunia dihebohkan dengan kemunculan Covid-19 (Corona Virus Disease 2019). Di Indonesia pertama kali diumumkan adanya dua kasus positif Covid-19 pada 2 Maret 2020. Namun, seorang Pakar Epidemiologi Universitas Indonesia (UI) Pandu Riono menyatakan bahwa virus corona jenis SARS-CoV-2 sebagai penyebab Covid-19 itu sudah masuk ke Indonesia sejak awal Januari 2020. Kemudian 17 hari setelah diumumkan, jumlah pasien positif Covid-19 terus bertambah (Kompas, 2020; Tribun Jabar, 2020).

Terjadinya pandemik Covid-19 ini berdampak pada seluruh sektor kehidupan, tak terkecuali sektor pendidikan. Pemerintah, dalam hal ini, Kementerian Pendidikan dan Kebudayaan, telah mengeluarkan beberapa regulasi terkait dengan pandemik Covid-19. Yang pertama adalah Surat Edaran Nomor 4 Tahun 2020 tentang Pelaksanaan Kebijakan Pendidikan dalam Masa Darurat Penyebaran Covid-19. Dalam surat edaran itu disebutkan bahwa kesehatan lahir dan batin seluruh unsur dalam pendidikan menjadi pertimbangan utama sehingga dikeluarkan kebijakan pendidikan masa darurat penyebaran Covid-19. Diantara poin dari kebijakan itu adalah pembatalan Ujian Nasional Tahun Ajaran 2018/2019 dan pembelajaran dilaksanakan dengan moda daring (dalam jaringan) (Menteri Pendidikan dan Kebudayaan Republik Indonesia, 2020).

Konsekuensi dari kebijakan pendidikan tersebut adalah ujian evaluasi akhir peserta didik dan penetapan kelulusan dilaksanakan oleh masing-masing satuan pendidikan, para guru harus siap melaksanakan pembelajaran secara daring, dan peserta didik harus siap untuk mengikuti pembelajaran dengan moda daring tersebut. Hal ini berdampak pula pada tugas kepengawasan. Para pengawas juga harus adaptif terhadap kondisi yang ada sebagai dampak dari pandemik Covid-19. Misalnya, pengawas tidak lagi memantau Ujian Nasional tetapi cukup memantau proses penilaian yang dilaksanakan oleh masing-masing satuan pendidikan dalam menetapkan kelulusan peserta didik. Kemudian dari segi proses pembelajaran, pengawas juga dituntut mampu melaksanakan pemantauan dan pembinaan secara daring. Ketika guru melaksanakan pembelajaran secara daring dengan menggunakan berbagai media daring, maka pengawas juga memantau kegiatan tersebut dengan teknik dan metode yang relevan.

Lalu pada 5 Juni 2020 Menteri Pemberdayaan Aparatur Negara dan Reformasi Birokrasi (PANRB) mengeluarkan surat edaran Nomor 58 Tahun 2020 tentang sistem kerja Aparatur Sipil Negara (ASN) pada New Normal atau kenormalan baru. Surat edaran ini memuat penyesuaian sistem kerja bagi ASN agar dapat beradaptasi terhadap perubahan tatanan normal baru yang produktif dan aman Covid-19. Adaptasi tersebut meliputi penyesuaian sistem kerja, dukungan sumber daya manusia aparatur, dan dukungan infrastruktur dengan memperhatikan protokol kesehatan (MENPANRRB, 2020). 
Sebagai tindak lanjut dari surat edaran tersebut Mendikbud bersama tiga menteri lainnya mengeluarkan Surat Keputusan Bersama tentang panduan penyelenggaraan pembelajaran pada tahun ajaran 2020/2021 di masa pandemik Covid-19. Dalam keputusan tersebut dijelaskan tentang kegiatan pembelajaran harus berpedoman pada pembagian zona wilayah pandemik Covid-19 berdasarkan tingkat resiko. Sekolah yang berada pada wilayah zona merah (resiko tinggi), oranye (sedang), dan kuning (rendah) harus tetap melaksanakan pembelajaran dengan cara daring. Sedangkan yang berada pada zona hijau (tidak terdampak) bisa melaksanakan pembelajaraan dengan cara luring (luar jaringan) atau tatap muka langsung tetapi setelah melalui proses perizinan dari pemerintah setempat, sekolah/madrasah, dan orang tua/wali peserta didik dan harus tetap memperhatikan protokol kesehatan (Republik Indonesia, 2020). Namun, berdasarkan data penyebaran Covid-19, 94\% atau 429 Kabupaten/Kota tergolong zona merah, oranye, dan kuning. Hanya $6 \%$ atau 85 Kabupaten/Kota yang tergolong zona hijau.

Setiap pemeritah daerah menetapkan kebijakan pelaksanaan pembelajaran sesuai dengan kategori zona wilayahnya masing-masing. Rata-rata daerah menetapkan pelaksanaan pembelajaran dilakukan dengan cara daring. Ada juga yang menetapkan pelaksanaan pembelajaran luring dengan metode kunjungan rumah yaitu guru mengelompokkan peserta didik dengan beberapa kelompok, setiap kelompok dibatasi hanya lima anggota, kemudian guru mengunjungi kelompok-kelompok tersebut untuk melaksanakan pembelajaran dengan menerapkan protokol kesehatan.

Ada sebuah pernyataan yang menarik kita cermati pada pidato Menteri Pendidikan dan Kebudayaan Republik Indonesia Nadiem Makarim pada upacara memperingati Hardiknas/Hari Pendidikan Nasional pada tanggal 2 Mei 2020, Mendikbud mengatakan ada hikmah dari adanya Pandemik Covid-19 ini, dimana kita bisa merasakan proses pembelajaran yang tidak dibatasi oleh ruang kelas, namun bisa dimanapun dan kapanpun. Dan ini adalah kali pertama dimana hampir seluruh tenaga pendidik di Indonesia melaksanakan proses pembelajaran lewat online atau daring. Memang kita sudah berada pada era revolusi industri 4.0 yang menuntut untuk semakin pintar memanfaatkan teknologi dalam memudahkan pekerjaan yang dilakukan. Namun, tidak bisa dipungkiri bahwa belum semua pihak siap menerima kondisi pembelajaran seperti ini, baik itu pihak guru sebagai tenaga pendidik maupun pihak siswa sebagai peserta didik.

Demikian halnya dengan pembinaan dan pemantauan yang dilakukan oleh pengawas tentu juga harus dilakukan dengan cara daring. Sebagaimana fungsi pengawas yaitu memastikan bahwa program pembelajaran yang dibuat oleh guru terlaksana sesuai dengan ketentuan yang ditetapkan pemerintah. Begitu pula pengawas harus melakukan pembinaan-pembinaan kepada guru-guru binaannya agar mereka dapat melaksanakan tugas dengan baik. Untuk menunjang tugas tersebut di masa pandemik tentu dibutuhkan aplikasi yang relevan dan efektif.

Pemanfaatan teknologi informasi pada masa pandemik ini merupakan sebuah keniscayaan yang tidak dapat lagi ditolak keberadaannya (Zahrawati \& Aras, 2020). Teknologi selalu mengalami perubahan dan perkembangan pada setiap zaman. Teknologi berkembang karena adanya manusia. Keberadaan manusia dan teknologi tidak dapat dipisahkan, kedua faktor tersebut pasti saling berkaitan. Perkembangan teknologi dipengaruhi oleh manusia, sebaliknya manusia juga dipengaruhi oleh perkembangan teknologi. Saat ini berada pada perkembangan era globalisasi yang hampir menyeluruh di setiap poros dunia. Maka siapa yang tidak mampu mengikuti arus 
perkembangan teknologi dengan baik akan tergilas oleh zaman. Juga dengan teknologi semakin canggih semakin mudah juga pekerjaan yang dilakukan manusia. Makruf (2009) mengutip pendapat Haag dan Keen bahwa teknologi informasi adalah seperangkat piranti yang membantu kita bekerja dengan informasi dan melakukan tugas yang berhubungan dengan pemerosesan informasi.

Berdasarkan hal tersebut, pertanyaan pada penelitian ini adalah: 1) Bagaimanakah melaksanakan pembinaan terhadap guru PAI dengan menggunakan Google Form? 2) Bagaimanakah melaksanakan pemantauan terhadap guru PAI dengan menggunakan Google Form? 3) Bagaimanakah meningkatkan kinerja guru PAI di masa pandemik? Adapun tujuan penelitian ini adalah melaksanakan pembinaan terhadap guru PAI menggunakan Google Form, melaksanakan pemantauan terhadap guru PAI menggunakan Google Form, dan meningkatkan kinerja guru PAI di masa pandemik. Selanjutnya, kontribusi yang diberikan dari penelitian ini adalah: 1) Mendorong peningkatan upaya masing-masing guru PAI untuk aktif, kreatif, dan inovatif dalam melasakanakan pembelajaran di masa pandemik. 2) Memudahkan pengendalian pembelajaran dan pemantauan kinerja guru PAI di masa pandemik. 3) Meningkatnya kompetensi guru dalam penggunaan media daring. 4) Meningkatnya mutu proses pembelajaran PAI. 5) Meningkatnya kinerja guru PAI.

\section{Metode Penelitian}

Penelitian ini merupakan penelitian survei. Lokasi penelitian adalah Kabupaten Bulukumba. Adapun responden penelitian adalah 27 guru Pendidikan Agama Islam di Sekolah Menengah Atas Bulukumba. Teknik pengumpulan data yang digunakan adalah angket dengan memanfaatkan Google Form.

\section{Pembahasan}

Penelitian ini dilaksanakan melalui beberapa kegiatan, yaitu: pembuatan instrument dengan Google Form, pembinaan, pemantauan, dan penyimpulan kinerja guru PAI.

\section{Pembuatan Instrumen dengan Google Form}

Google Form adalah teknologi serbaguna untuk mengelola data seperti pendaftaran acara, membuat polling quick count, dan masih banyak lagi. Dengan Google Form, kita juga dapat membuat dan menganalisis survei dengan cepat secara online dan mendapatkan hasil instan. Bukan cuma itu, kita bisa meringkas hasil survei dengan diagram dan grafik. Google Form adalah semua yang kita butuhkan untuk mengumpulkan informasi penting dengan mudah (www.sepulsa.com).

Google Form bersama dengan Documents, Spreadsheet, dan Slide adalah bagian dari rangkaian aplikasi online Google untuk membantu kita menyelesaikan lebih banyak pekerjaan secara gratis (www.sepulsa.com).

Termasuk dalam pembinaan dan pemantauan oleh pengawas secara daring, instrumennya dapat dikembangkan dengan menggunakan Google Form. Berikut ini tata cara membuat Google Forms:

1. Dari form.google.com, klik Blank atau pilih template.

2. Dari drive.google.com, klik New > Lainnya. Di samping Google Forms, arahkan ke Panah kanan dan klik Blank form or From a template. 
3. Namai formulir Anda: Di pojok kiri atas, klik Untitled form atau nama formulir template dan masukkan nama baru.

4. (Opsional) Tambahkan deskripsi: Di bawah nama form, tambahkan teks Anda.

5. (Opsional) Ubah warna latar belakang atau tema: Klik Palette (Palet Warna) lalu pilih warna atau tema (www.sepulsa.com).

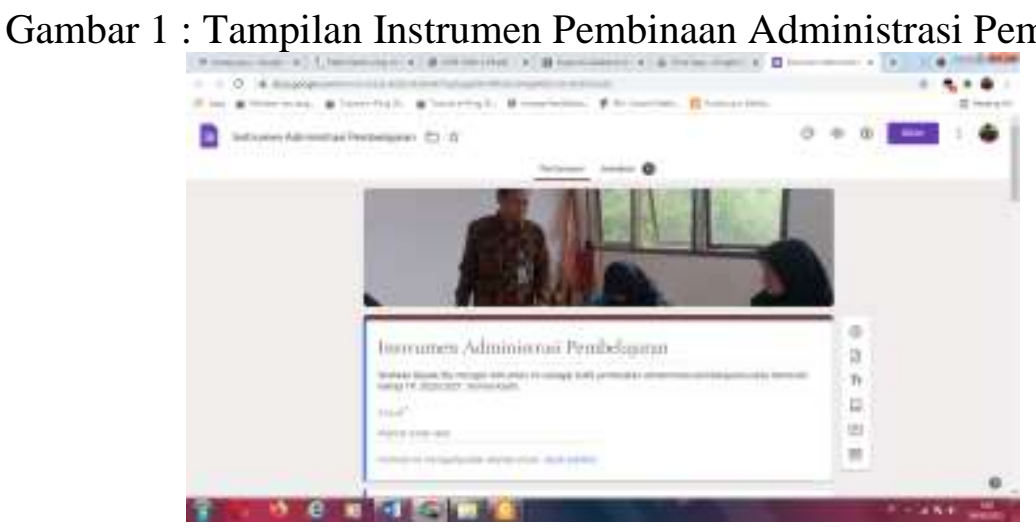

Gambar 2 : Tampilan Instrumen Google Forms

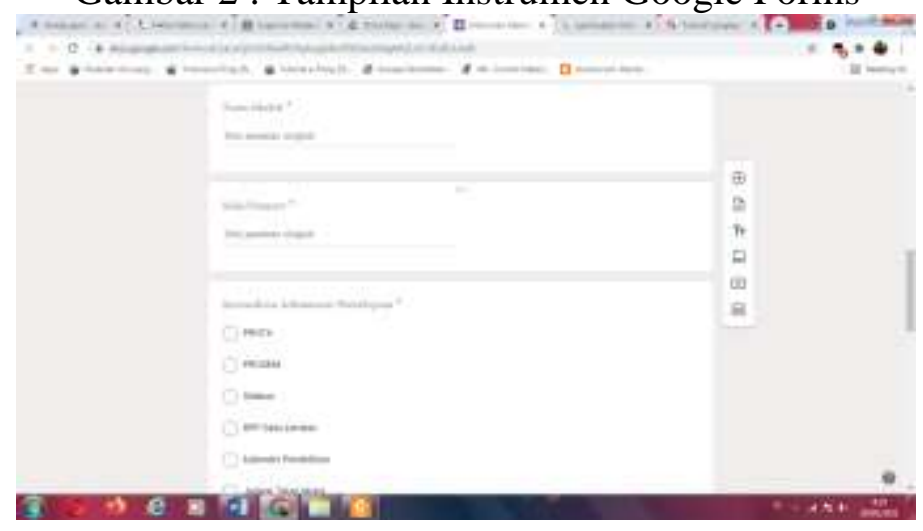

\section{Pembinaan Guru PAI}

Dalam masa pandemik ini pembinaan dilaksanakan secara daring sehingga pengawas dituntut untuk kreatif dan inovatif dalam melaksanakan tugas. Google Form sangat membantu tugas pengawas dalam pembinaan guru PAI. Tinggal bagaimana upaya pengawas dalam memanfaatkan Google Form sesuai tugas dan fungsi pengawas. Efektivitas pembinaan daring tentu harus didukung juga dengan ketersediaan jaringan internet yang baik bagi pengawas dan guru.

Dalam masa pandemik ini, dimanfaatkan Google Form dalam pembinaan guru PAI. Instrumen yang telah dikembangkan dalam bentuk manual kemudian diformat dalam bentuk insrtumen Google Form sesuai dengan langkah-langkah pembuatan Google Form. Sangatlah mudah membuat instrumen Google Form karena dalam fiturfiturnya telah tersedia pilihan-pilihan format sesuai kebutuhan. Misalnya untuk mengecek ketersediaan dokumen administrasi pembelajaran digunakan format "Kotak Centang", untuk meminta guru PAI mengirim file Rencana Pelaksanaan Pembelajaran (RPP) atau file lainnya digunakan format Upload File, dan lain-lainnya.

Setelah instrumen Google Form selesai maka link instrumen tersebut disalin lalu dikirim ke guru PAI binaan melalui grup WhatsApp (WA). Link itu kemudian dibuka oleh guru PAI binaan lalu diisi sesuai dengan keadaannya masing-masing. Dari 27 guru 
binaan, hanya 13 orang yang merespon instrumen tersebut. Berbagai kendala menjadi penghambat dalam pembinaan daring ini, salah satunya adalah ketidakaktifan guru pada grup WA sehingga instrumen terlewatkan dan tidak dibuka. Kendala lainnya adalah sikap acuh guru untuk merespons instrumen daring oleh karena kurang terjalinnya hubungan secara emosional dengan pengawas. Begitu pula bagi guru-guru yang berada di wilayah yang koneksi internetnya kurang baik akan sulit merespon. Dan lain-lain kendala yang dihadapi guru dalam pengawasan daring.

Dalam pembinaan administrasi pembelajaran masih ada guru yang belum melengkapi standar administrasi pembelajaran. Rata-rata guru sudah mengembangkan RPP satu lembar sebagaimana yanng diamanahkan dalam Surat Edaran Menteri Pendidikan Nasional No. 14 tahun 2019. Pengembangan RPP satu lembar dimaksudkan untuk mengurangi beban guru dalam penyusunan administrasi pembelajaran. Dan ini merupakan suatu terobosan yang sangat baik demi efektivitas dan efisiensi pelaksanaan pembelajaran.

Hasil dari pembinaan ini kemudian ditindaklanjuti dengan menyampaikan saran dan masukan kepada guru PAI binaan. Bagi yang sudah lengkap administrasi pembelajarannya disarankan untuk melakukan inovasi-inovasi dalam pelaksanaan pembelajaran secara daring. Bagi yang belum lengkap diberi tugas untuk segera melengkapi dengan berkomunikasi dengan guru PAI yang sudah lengkap dan atau melakukan penelusuran melalui browsing internet atau menonton melalui YouTube tentang tata cara penyusunan administrasi yang belum dilengkapi. Tidak lupa juga penulis mengirimkan contoh-contoh administrasi melalui grup WA sebagai bahan pembanding bagi guru-guru.

Dari hasil pembinaan ini penulis menemukan bahwa pengawasan secara daring masih belum efektif sehingga masih perlu upaya-upaya pengembangan oleh pengawas dalam mengaktifkan guru-guru binaan dalam merespon instrumen secara daring. Ketidakefektifan tersebut bukanlah pengaruh dari format instrumen yang menggunakan Google Form, tetapi pada umumnya dipengaruhi oleh pola pikir guru-guru yang baru beradaptasi dengan masa kenormalan baru sehingga menganggap bahwa pembelajaran dan juga pengawasan daring tidak akan efektif.

Jadi, menjadi tugas dan tanggung jawab besar bagi seorang pengawas dalam merubah pola pikir guru untuk terus berkarya dalam kondisi apa pun dengan berbagai kreativitas dan inovasi sehingga pembelajaran dan juga pengawasan daring dapat terlaksana dengan baik dan berhasil.

Tabel 1. Rekapiltulasi Hasil Pembinaan Administrasi Pembelajaran Menggunakan Google Form

\section{No Informan Ketersediaan Administrasi $\quad$ Kendala}

\begin{tabular}{|c|c|c|c|}
\hline 1 & $\mathrm{AA}$ & RPP Satu Lembar & $\begin{array}{l}\text { Jaringan bagi siswa dan guru } \\
\text { serta adanya siswa yg tdak ada } \\
\text { sarana dan prasarana } \\
\text { pembelajaran } \text { online }\end{array}$ \\
\hline 2 & $\mathrm{AB}$ & Daftar Hadir Peserta Didik & Jaringan \\
\hline 3 & $\mathrm{AC}$ & Jadwal Tatap Muka & - \\
\hline
\end{tabular}


4

$5 \quad \mathrm{AE}$

$6 \mathrm{AX}$

$7 \quad \mathrm{AF}$

$8 \quad \mathrm{AG}$

$9 \mathrm{AH}$

10 AJ

11 AK

$12 \mathrm{AL}$

13 AM
Daftar Hadir Peserta Didik

PROTA, PROSEM, Silabus, RPP Satu Lembar, Kalender Pendidikan, Jadwal Tatap Muka, Agenda Harian, Daftar Nilai, Daftar Hadir Peserta Didik

PROTA, PROSEM, Silabus, RPP Satu Lembar, Kalender Pendidikan, Jadwal Tatap Muka, Agenda Harian, Daftar Nilai, KKM, Daftar Hadir Peserta Didik

RPP Satu Lembar

PROTA, PROSEM, Silabus, RPP Satu Lembar, Kalender Pendidikan, Jadwal Tatap Muka, Agenda Harian, Daftar Nilai, KKM, Daftar Hadir Peserta Didik

PROTA, PROSEM, Silabus, RPP Satu Lembar, Jadwal Tatap Muka, Agenda Harian, Daftar Nilai, KKM, Daftar Hadir Peserta Didik

PROTA, PROSEM, RPP Satu Lembar

PROTA, PROSEM, Silabus, RPP Satu Lembar, Kalender Pendidikan, Jadwal Tatap Muka, Agenda Harian, Daftar Nilai, Daftar Hadir Peserta Didik

PROTA, PROSEM, Silabus, RPP Satu Lembar, Kalender Pendidikan, Jadwal Tatap Muka, Agenda Harian, Daftar Nilai, KKM, Daftar Hadir Peserta Didik

RPP Satu Lembar, Kalender Pendidikan, Jadwal Tatap Muka, Agenda Harian, Daftar Nilai, Daftar Hadir Peserta Didik
Jaringan yg kurang memadai

Pada saat pembelajaran jaringan kurang mendukung

Merubah file excel ke word

Sarana dan Prasarana

Jaringan internet yang kurang lancar

Belum ada perangkat pandemik, disibukkan juga dengan buat laporan mengajar perhari, perminggu dan laporan kinerja, sibuk wali kelas mengawal peserta didik dari jauh yang sangat menantang, melelahkan sebab siswa kurang tertarik ikut belajar BJJ. Meski telah dibagikan kartu data

Pada saat pembelajaran jaringan kurang mendukung 


\section{Pemantauan Guru PAI}

Demikian halnya pemantauan guru PAI juga dilaksanakan secara daring. Maka penggunaan Google Form menjadi alternatif dalam pemantauan daring. Pemantauan yang dilaksanakan dengan menggunakan Google Form adalah pemantauan kegiatan awal semester dan pemantauan proses pembelajaran daring.

Instrumen pemantauan awal semester dan pemantauan proses pembelajaran yang telah dikembangkan kemudian diformat dalam bentuk instrumen Google Form sebagaimana halnya instrumen pembinaan. Instrumen pemantauan awal semester terdiri atas permintaan data tentang jumlah jam pelajaran, kelas yang diajar, hari aktif, dan tugas tambahan. Sedangkan instrumen pemantauan proses pembelajaran terdiri atas permintaan data tentang nama kelas, materi pokok, kompetensi dasar/indikator, metode pembelajaran, media pembelajaran, sumber belajar, moda pembelajaran, Learning Management System (LMS) yang digunakan, jumlah siswa keseluruhan, jumlah siswa yang aktif, dan upload foto pembelajarn.

Selanjutnya link instrumen tersebut disalin lalu dikirim ke guru PAI binaan melalui grup WhatsApp (WA). Link itu kemudian dibuka oleh guru PAI binaan lalu diisi sesuai dengan data dan pelaksanaan masing-masing. Dari 27 guru binaan, ada 20 orang yang merespon instrumen pemantauan awal semester dan hanya 9 orang yang merespon instrumen pemantauan proses pembelajaran.

Dalam pemantauan awal semester rata-rata guru PAI sudah memberikan data dengan baik. Data tersebut menjadi dasar bagi penulis dalam menentukan layak tidaknya seorang guru mendapatkan tunjangan dan dasar dalam penyusunan program pembinaan dan pemantauan. Misalnya data tentang jumlah jam pelajaran dan tugas tambahan menjadi dasar dalam penetapan layak atau tidaknya mendapatkan tunjangan profesi bagi yang sudah memiliki sertifikat pendidik dan menjadi dasar penetapan pemberian tunjangan tambahan bagi guru yang belum bersertifkat pendidik. Data tentang hari aktif dan kelas yang diajar menjadi bahan bagi pengawas dalam menyusun jadwal pembinaan dan pemantauan.

Dalam pemantauan proses pembelajaran terlihat bahwa guru-guru PAI melaksanakan pembelajaran secara daring dengan beberapa LMS yang digunakan. Salah satu LMS yang digunakan adalah Google Classroom. Guru membuat kelas di Google Classroom lalu memasukkan semua siswa dalam satu kelas, lalu guru mengupload materi dan tugas yang harus direspon oleh siswa melalui kelas tersebut, termasuk penulis sebagai pengawas ikut bergabung dalam kelas tersebut untuk memantau secara daring kegiatan pembelajaran tersebut. Ada juga yang menggunakan Microsoft Teams dimana guru sebagai pemilik tim, guru memberikan pekerjaan, berbagi konten kelas, memulai rapat, dan mengontrol siapa yang bisa memposting di tim. Setiap tim kelas juga tertaut pada Buku Catatan Kelas OneNote. Bahkan ada juga pembelajaran yang menggunakan media grup WA dimana guru membuat sendiri yang membuat grup WA lalu mengundang atau memasukkan siswa untuk bergabung di dalam satu grup satu kelas, di dalam grup itulah guru menyampaikan berbagai tugas yang harus dilakukan oleh siswa kemudian siswa juga merespon tugas tersebut dengan mengirim kembali dalam grup sesuai tagihan tugas yang diberikan.

Dari pemantauan itu ditemukan bahwa guru-guru yang sudah memiliki kompetensi dalam menggunakan beberapa bentuk LMS, seperti Google Classroom dengan Microsoft Teams, dapat menggunakan LMS tersebut dengan baik. Sementara guru yang belum menguasai LMS tersebut masih menggunakan media grup WA sebagai alternatif dalam pembelajaran daring. Kelemahan penggunaan media grup WA 
adalah penyimpanan data tidak terkoneksi dengan email sehingga ketika data terhapus maka akan kehilangan data tersebut.

\section{Kinerja Guru PAI}

Dari hasil pembinaan dan pemantauan yang dilaksanakan dengan menggunakan Google Form tergambar bahwa ada beberapa faktor yang mermpengaruhi kinerja guru PAI di masa pandemi ini, yaitu: pola pikir guru PAI tentang pembelajaran daring, tingkat kompetensi guru PAI dalam mengoperasikan Learning Management System (LMS), dan ketersediaan jaringan internet.

Beberapa guru yang tidak merespon instrumen dari pengawas masih memiliki pola pikir bahwa pembelajaran daring tidak akan efektif sehingga pengawasan daring pun akan sulit terlaksana. Hal ini itu lahir dari sikap apatis yang tidak terdorong untuk melakukan kreasi dan inovasi. Padahal sesungguhnya dalam kondisi bagaimana pun pembelajaran harus diupayakan berlangsung secara efektif dengan berbagai metode dan teknik yang bisa dikembangkan.

Guru yang merespon dengan baik instrumen dari pengawas merupakan guru-guru yang selalu berpikiran maju dan ingin melihat keberhasilan pembelajaran itu harus terwujud dalam kondisi apa pun dan bagaimana pun. Inilah salah satu ciri guru yang kreatif dan inovatif dalam menyikapi kondisi masa pandemik walaupun ada pembatasan tetapi mereka senantiasa berupaya mencari cari untuk tetap melaksanakan pembelajaran secara daring.

Tingkat kompetensi guru dalam memanfaatkan Learning Management System (LMS) juga menjadi salah satu faktor yang mempengaruhi efektivitas pembelajaran daring (Zahrawati \& Nurhayati, 2021). Guru yang sudah menggunakan Google Classroom dan Microsoft Teams dalam pembelajaran daring menunjukkan bahwa mereka sudah setingkat lebih maju dibadingkan dengan yang masih menggunakan media sosial semacam WA. Penggunaan aplikasi semacam Google Classroom akan memudahkan bagi guru dalam mengelola pembelajaran karena fitur-fitur di dalamnya memang sudah dirancang khusus untuk pembelajaran. Demikian halnya dengan Microsoft Teams.

Ketersediaan jaringan internet menjadi salah satu kedala yang dihadapi oleh guru dalam pembelajaran daring. Ada wilayah tertentu yang memiliki sinyal yang lemah untuk jaringan internet. Mereka harus mencari tempat yang kuat sinyalnya untuk bisa melakukan pembelajaran daring sehingga terkadang agak lambat melaksanakannya dan begitu juga merespon instrumen dari pengawas.

Temuan ini sejalan dengan beberapa penelitian terkait pelaksanaan pembelajaran daring di masa pandemik Covid-19, bahwa jaringan internet yang tidak stabil menjadi kendala pelaksanaan pembelajaran daring. Selain itu, kemampuan guru dalam memanfaatkan media pembelajaran daring juga menjadi kendala dalam mewujudkan pembelajaran daring yang maksimal (Zahrawati \& Ramadani, 2021).

\section{Kesimpulan}

Google Form menjadi salah satu alternatif dalam mengembangkan instrumen pembinan dan pemantauan di masa pandemik. Dibutuhkan kreativitas dan inovasi oleh seorang pengawas dalam menghadapi kondisi seperti ini. Dengan Google Form semua bentuk pembinaan dan pemantauan dapat terlaksana secara daring. Pembinaan dengan Google Form mendapat respon yang bermacam-macam dari guru. Ada yang merespon 
dengan sangat baik dan ada yang tidak merespon sama sekali. Guru yang merespon dengan sangat baik merupakan suatu tanda kemajuan karena mereka sudah selalau siap dengan berbagai kondisi. Sementara yang tidak merespon sama sekali menunjukkan kemunduran karena tidak mau mengikuti laju perkembangan teknologi pembelajaran. Demikian halnya dalam pemantauan dengan Google Form. Aplikasi ini sangat membantu bagi pengawas dalam menyampaikan instrumen pemantauan. Pengawas tidak perlu lagi direpotkan dengan penggandaan instrumen tetapi cukup sekali membuat link itulah yang disebar ke semua guru binaan. Ini bisa menghemat waktu dan anggaran sekaligus. Dari hasil pengamatan penulis, kinerja guru PAI di masa pandemi berbedabeda antara satu guru dengan guru lainnya. Guru yang merespon dengan baik berbanding lurus dengan tingkat kinerjanya, artinya mereka memiliki kinerja yang tinggi, demikian pula sebaliknya. Berbagai hal menjadi kendala dalam pelaksanaan pembelajaran daring tetapi bisa ditasai dengan baik oleh guru yang berkinerja tinggi. Sebaliknya guru yang berpikir apatis akan mengkambinghitamkan masa pandemi ini untuk melaksanakan tugas secara apa adanya saja. Dari temuan ini, beberapa hal yang perlu direkomendasikan adalah sebagai berikut: guru yang sudah menunjukkan kinerja yang baik untuk terus mengembangkan kemampuan yang dimilikinya serta dapat menularkan pengetahuannya kepada teman-teman sejawat, guru yang masih menunjukkan kinerja rendah supaya berupaya mengejar ketertinggalan, utamanya dalam pemanfaatan LMS dalam pembelajaran daring, dan pengawas harus terus meningkatkan pembinaan dan pemantauan dengan memanfaatkan berbagai media dan atau aplikasi yang relevan untuk menjamin kualitas pembelajaran di masa pandemik.

\section{Referensi}

Kompas. (2020). Diumumkan awal Maret, ahli: Virus Corona masuk Indonesia dari Januari. $\quad$ Retrieved June 20, 2020, from https://www.kompas.com/sains/read/2020/05/11/130600623/diumumkan-awalmaret-ahli--virus-corona-masuk-indonesia-dari-januari

Makruf, I. (2009). Strategi pembelajaran bahasa Arab aktif. Semarang: Need's Press.

MENPANRRB, H. (2020). Berdaya Srikandi Oleh Srikandi, Peran Perempuan Tingkatkan Kesejahteraan Masyarakat Parepare. Retrieved from https://www.menpan.go.id/site/berita-terkini/berdaya-srikandi-oleh-srikandi-peranperempuan-tingkatkan-kesejahteraan-masyarakat-parepare

Menteri Pendidikan dan Kebudayaan Republik Indonesia. Surat Edaran Nomor 4 Tahun 2020 tentang Pelaksanaan Kebijakan Pendidikan dalam Masa Darurat Penyebaran Coronavirus Disease (Covid-19). , (2020).

Republik Indonesia. Keputusan bersama Menteri Pendidikan dan Kebudayaan, Menteri Agama, Menteri Kesehatan, dan Menteri dalam Negeri Republik Indonesia tentang panduan penyelenggaraan pembelajaran pada tahun ajaran 2020/2021 dan tahun akademik 2020/2021 di masa pandemi Corona. , (2020).

Tribun Jabar. (2020). Awal mula pandemi Covid-19 di Indonesia, di awali dari klub dansa kini tersebar di 16 Provinsi. Retrieved June 20, 2020, from https://jabar.tribunnews.com/2020/03/23/awal-mula-pandemi-covid-19-diindonesia-di-awali-dari-klub-dansa-kini-tersebar-di-16-provinsi?page $=2$

Zahrawati, F., \& Aras, A. (2020). Pembelajaran Berbasis Riset dengan Memanfaatkan Google Classroom pada Mahasiswa Tadris Ilmu Pengetahuan Sosial. Jurnal Ilmiah 
Iqra', 14(2), 143-154.

Zahrawati, F., \& Nurhayati. (2021). The challenge of online learning in curriculum2013 during COVID-19 pandemic: study of social science teachers at MAN 2 Parepare. Sociological Education, 2(1), 9-14.

Zahrawati, F., \& Ramadani, A. N. (2021). Problematika implementasi kurikulum 2013 terhadap proses pembelajaran pada masa pandemik COVID-19. Bidayatuna: Jurnal Pendidikan Guru Madrasah Ibtidaiyah, 04(01), 59-74. 